Indonesian Journal of Physics and Nuclear Applications

Volume 3, Number 3, October 2018, p. 95-101

e-ISSN 2550-0570, (C) FSM UKSW Publication

\title{
THE DOSE ANALYSIS OF BORON NEUTRON CAPTURE THERAPY (BNCT) TO THE BRAIN CANCER (GLIOBLASTOMA MULTIFORM) USING MCNPX-CODE WITH NEUTRON SOURCE FROM COLLIMATED THERMAL COLUMN KARTINI RESEARCH NUCLEAR Kholidah Hasyim NM${ }^{1}$, Y. Sardjono², Yosaphat Sumardi ${ }^{1}$
}

\author{
${ }^{I}$ Physics Department, Mathematics and Natural Science Faculty, Yogyakarta State University, \\ Karangmalang, Yogyakarta \\ ${ }^{2}$ Center of Accelerator and Material Process Technology - BATAN \\ Email: yudhakholidha@gmail.com
}

\begin{abstract}
This research was aimed at discovering the optimum concentration of Boron-10 in concentrations range 20 $\mu$ gram/gram until $35 \mu$ gram/gram with Boron Neutron Capture Therapy (BNCT) methods and the shortest time irradiation for cancer therapy. The research about dose analysis of Boron Neutron Capture Therapy (BNCT) to the brain cancer (Glioblastoma Multiform) using MCNPX-Code with a neutron source from Collimated Thermal Column Kartini Research Nuclear has been conducted. This research was a simulation-based experiment using MCNPX, and the data was arranged on a graph using OriginPro 8 . The modelling was performed with the brain that contains cancer tissue as a target and the reactor as a radiation source. The variations of Boron concentrations in this research was on $20,25,30$ and $35 \mu \mathrm{g} / \mathrm{gram}$ tumours. The outputs of MCNP were neutron scattering dose, gamma ray dose and neutron flux from the reactor. Neutron flux was used to calculate the doses of alpha, proton and gamma rays produced by the interaction of tissue material and thermal neutrons. Based on the calculations, the optimum concentration of Boron-10 in tumour tissue was for a $30 \mu \mathrm{g} / \mathrm{gram}$ tumour with the radiation dose in skin at less than $3 \mathrm{~Gy}$. The irradiation times required were 2.79 hours for concentration $20 \mu \mathrm{g} / \mathrm{gram} ; 2.78$ hours for concentration $25 \mu \mathrm{g} / \mathrm{gram} ; 2.77$ hours for concentration $30 \mu \mathrm{g} / \mathrm{gram} ; 2.8$ hours for concentration $35 \mu \mathrm{g} / \mathrm{gram}$.
\end{abstract}

Keywords BNCT, Brain cancer, boron concentration, irradiation time.

\section{INTRODUCTION}

Cancer is the disease which gets special attention because of its lethal and benign characteristics (American Cancer Society, 2014). Some treatment methods for cancer are radiotherapy, surgery and chemotherapy. The surgery method is that of taking cancer out of the human body. This method is usually used for the first stage of cancer where the cancer is benign and it does not spread to another of the body's tissues (Cember, Johnson, \& Alaei, 2009; Sudhakar, 2009). Chemotherapy methods can be combined with surgery, utilizing drugs to kill the cancerous tissue (Cember et al., 2009).
The new technology of radiotherapy that may be used for cancer treatment is Boron Neutron Capture Therapy (BNCT). BNCT is a cancer therapy technique that uses the physics principles of nuclear reactions which occur when Boron-10 is irradiated by low energy neutrons (thermal neutrons). This reaction between boron and thermal neutrons produces Boron-11 ( $\mathrm{t}_{1 / 2}=10^{-23}$ second). Boron$11 \mathrm{~m}$ decays by emitting alpha particle, Lithium-7 particle and gamma ray. In BNCT, Boron-10 and its carrier drug are administered to the patient. This carrier will take the compound to the location of the cancer tissue where Boron-10 needs to be accumulated. 
Then the cancer area is irradiated by neutron source (Bakirdere, Orenay, \& Korkmaz, 2010). Boron-10 in the cancer tissue will capture the thermal neutron resulting from a prompt nuclear reaction Boron-10(n, $\alpha)$ Lithium-7. Both $\gamma$-particle and Lithium-7 have relatively high Linear Energy Transfer (LET) values (175 keVmn and above) and short path lengths (approximately 4.5 to $10 \mu \mathrm{m}$ ), hence the energy deposition is locally limited around the cancer tissue (W. Sauerwein, 1993).

Lithium has a dose limit in the human body amounting to $900-1800 \mathrm{mg} /$ day or 1.5 $2.5 \mathrm{meQ} / \mathrm{L}$. Lithium concentrations exceeding $3.5 \mathrm{meQ} / \mathrm{L}$ are fatal for humans. The ratio of Boron-10 concentrations in cancer tissue and health tissue was $10: 1$ so that the research is selective because the neutron reaction probability with Boron-10 is greater in cancer tissue(W. A. G. Sauerwein \& Moss, 2009).

\section{MATERIAL AND METHODS}

This study was a simulation-based experiment using MCNPX. In the first step, it was necessary to make a model of the reactor since it would be used as the neutron source. Several parts of the reactor were modelled, such as core, the radial reflector, rotary specimen rack, and piercing beam port. The thermal column was also built since it would become the point of interest. Simulation was done to make sure that the criticality value was approximately 1 , and the thermal neutron flux in the ring $\mathrm{B}$ was approximately $(12.45 \pm 0.23)$ $\mathrm{x} 10^{11} \mathrm{n} . \mathrm{cm}^{-2} \cdot \mathrm{s}^{-1}$ (Fauziah Nina, Widiharto, $\&$ Sardjono, 2015). The result should be recorded for the next collimator conceptual design process. In an MCNP input file, tallies are the information that a user wants to obtain by Monte Carlo calculation. According to the beam criteria in Table 1, the tallies were needed for resulting fluxes and current data. Neutron and gamma fluxes were calculated by using F4 tally and corresponding dose values were determined using fluence to kerma conversion factors reported in ICRU 63. Moreover, neutron current was calculated using F1 tally. Normalization factors for each tally were calculated for normalizing the tallies reactor within $100 \mathrm{~kW}$ thermal power.

Secondly, the collimator was designed. A rough collimator design was made by using MCNPX codes: $95 \mathrm{~cm}$ length of collimator, 54 $\mathrm{cm}$ of outer collimator diameter, $3 \mathrm{~cm}$ thick of beam delimiter, and $3 \mathrm{~cm}$ sized aperture. The beam delimiter was made of 6Li2CO3polyethylene. In designing the collimator, one should start with the varied sizes of the collimator wall. The material used was Ni. The best thickness would be that which provided the highest epithermal neutron flux. Then, moderator, Al, was varied until the fast neutron component decrease was no longer significant. In this point, ${ }_{60} N i$, which served as a fast neutron absorber, also absorbed the thermal neutrons, and started to be used and varied until the fast and thermal neutron components were reached.

The next step was to employ $\mathrm{Bi}$ as gammaray shielding into the collimator and alter its thickness until the desired gamma-ray component was gained. The last parameter of beam quality was the examination of the direction of the collimator. If the direction of the collimator was less than desired, more beam delimiter would be added. The last step conducted was setting the aperture or the beam cross section size to find out the performance of the collimator design.

The modelling of brain geometry was ellipsoid with diameters $x$ axis was $21.2 \mathrm{~cm}$. The cancer location in a lobus frontalis with 
$3.3 \mathrm{~cm}$ of deepness from skin surface. In this simulation, we used a $0.6 \mathrm{~cm}$ thickness of scalp, a $0.6 \mathrm{~cm}$ thickness of cranium, a $0.6 \mathrm{~cm}$ thickness of cranium, a16.7 cm thickness of soft tissue, a $0.3 \mathrm{~cm}$ thickness of Planning Tumor Volume (PTV), a $0.5 \mathrm{~cm}$ thickness of Clinical Tumor Volume (CTV), and a $4 \mathrm{~cm}$ diameter of Gross Tumor Volume (GTV) or cancer).

\section{RESULT AND DISCUSSION}

Thermal neutron source was produced by the model of Collimated Thermal Column Kartini Research Nuclear Reactor. The neutron criteria of thermal column outputs was shown at Table 1 (IAEA, 2014).

Table 1. Neutron criteria of collimated thermal column outputs.

\begin{tabular}{ll}
\hline \multicolumn{1}{c}{ Parameter } & \multicolumn{1}{c}{ Values } \\
\hline$\phi_{\text {epi }}\left(n \cdot \mathrm{cm}^{-2} \cdot \mathrm{s}^{-1}\right)$ & $1.65 \times 10^{9}$ \\
$\dot{D_{f}} / \phi_{\text {epi }}\left(G y \cdot \mathrm{cm}^{2} \cdot \mathrm{n}^{-1}\right)$ & $1.59 \times 10^{-13}$ \\
$\dot{D_{\gamma}} / \phi_{\text {epi }}\left(G y \cdot \mathrm{cm}^{2} \cdot \mathrm{n}^{-1}\right)$ & $1.16 \times 10^{-13}$ \\
$\phi_{\text {th }} / \phi_{\text {epi }}$ & 0.007 \\
$\mathrm{~J} / \phi_{\text {epi }}$ & 0.72 \\
\hline
\end{tabular}

Table 2. The outputs of collimated thermal column.

\begin{tabular}{|c|c|c|c|c|}
\hline Cell & Name & $\begin{array}{l}\text { Termal Flux } \\
\left(\text { n. } \mathrm{cm}^{-3} \cdot \mathrm{s}^{-1}\right)\end{array}$ & Epiermal Flux $\left(\mathrm{n} \cdot \mathrm{cm}^{-3} \cdot \mathrm{s}^{-1}\right)$ & $\begin{array}{l}\text { Fast Neutron } \\
\left(\text { n. } \mathrm{cm}^{-3} \cdot \mathrm{s}^{-1}\right)\end{array}$ \\
\hline \multirow[t]{2}{*}{134} & Before reached skin & 2.011 & 1.161 & $5.53 \mathrm{E}+07$ \\
\hline & & $\mathrm{E}+08$ & $\mathrm{E}+09$ & \\
\hline \multirow[t]{2}{*}{8} & scalp & 9.557 & 8.909 & $5.10 \mathrm{E}+05$ \\
\hline & & $\mathrm{E}+07$ & $\mathrm{E}+07$ & \\
\hline \multirow[t]{2}{*}{9} & cranium & 6.670 & 5.854 & $0.00 \mathrm{E}+00$ \\
\hline & & $\mathrm{E}+07$ & $\mathrm{E}+07$ & \\
\hline \multirow[t]{2}{*}{10} & soft tissue & 1.386 & 1.808 & $0.00 \mathrm{E}+00$ \\
\hline & & $\mathrm{E}+07$ & $\mathrm{E}+07$ & \\
\hline \multirow[t]{2}{*}{11} & cerebrum & 6.652 & 1.993 & $0.00 \mathrm{E}+00$ \\
\hline & & $\mathrm{E}+07$ & $\mathrm{E}+08$ & \\
\hline \multirow[t]{2}{*}{12} & PTV & 2.30 & 9.511 & $0.00 \mathrm{E}+00$ \\
\hline & & $3 \mathrm{E}+06$ & $\mathrm{E}+06$ & \\
\hline \multirow[t]{2}{*}{13} & CTV & 6.217 & 3.848 & $0.00 \mathrm{E}+00$ \\
\hline & & $\mathrm{E}+05$ & $\mathrm{E}+06$ & \\
\hline \multirow[t]{2}{*}{14} & GTV & 1.374 & 7.265 & $0.00 \mathrm{E}+00$ \\
\hline & & $\mathrm{E}+05$ & $\mathrm{E}+05$ & \\
\hline 17 & slice & 5.021 & 3.094 & $0.00 \mathrm{E}+00$ \\
\hline
\end{tabular}




\begin{tabular}{|c|c|c|c|c|}
\hline & & $\mathrm{E}+07$ & $\mathrm{E}+07$ & \\
\hline \multirow[t]{2}{*}{18} & slice & 0.000 & 0.000 & $0.00 \mathrm{E}+00$ \\
\hline & & $\mathrm{E}+00$ & $\mathrm{E}+00$ & \\
\hline \multirow[t]{2}{*}{19} & slice & 0.000 & 0.000 & $0.00 \mathrm{E}+00$ \\
\hline & & $\mathrm{E}+00$ & $\mathrm{E}+00$ & \\
\hline \multirow[t]{2}{*}{20} & slice & 0.000 & 0.000 & $0.00 \mathrm{E}+00$ \\
\hline & & $\mathrm{E}+00$ & $\mathrm{E}+00$ & \\
\hline \multirow[t]{2}{*}{21} & slice & 0.000 & 0.000 & $0.00 \mathrm{E}+00$ \\
\hline & & $\mathrm{E}+00$ & $\mathrm{E}+00$ & \\
\hline 24 & slice & $0.000 \mathrm{E}+00$ & $0.000 \mathrm{E}+00$ & $0.00 \mathrm{E}+00$ \\
\hline \multirow[t]{2}{*}{25} & slice & 0.000 & 0.000 & $0.00 \mathrm{E}+00$ \\
\hline & & $\mathrm{E}+00$ & $\mathrm{E}+00$ & \\
\hline \multirow[t]{2}{*}{26} & slice & 0.000 & 0.000 & $0.00 \mathrm{E}+00$ \\
\hline & & $\mathrm{E}+00$ & $\mathrm{E}+00$ & \\
\hline \multirow[t]{2}{*}{27} & slice & 0.000 & 0.000 & $0.00 \mathrm{E}+00$ \\
\hline & & $\mathrm{E}+00$ & $\mathrm{E}+00$ & \\
\hline 28 & slice & $0.000 \mathrm{E}+00$ & $0.000 \mathrm{E}+00$ & $0.00 \mathrm{E}+00$ \\
\hline \multirow[t]{2}{*}{29} & slice & 0.000 & 0.000 & $0.00 \mathrm{E}+00$ \\
\hline & & $\mathrm{E}+00$ & $\mathrm{E}+00$ & \\
\hline \multirow[t]{2}{*}{30} & slice & 0.000 & 0.000 & $0.00 \mathrm{E}+00$ \\
\hline & & $\mathrm{E}+00$ & $\mathrm{E}+00$ & \\
\hline \multirow[t]{2}{*}{31} & slice & 0.000 & 0.000 & $0.00 \mathrm{E}+00$ \\
\hline & & $\mathrm{E}+00$ & $\mathrm{E}+00$ & \\
\hline \multirow[t]{2}{*}{32} & slice & 0.000 & 0.000 & $0.00 \mathrm{E}+00$ \\
\hline & & $\mathrm{E}+00$ & $\mathrm{E}+00$ & \\
\hline \multirow[t]{2}{*}{33} & slice & 0.000 & 0.000 & $0.00 \mathrm{E}+00$ \\
\hline & & $\mathrm{E}+00$ & $\mathrm{E}+00$ & \\
\hline
\end{tabular}

Table 2 shows flux of boron concentration $35 \mu$ gram/gram. The others, (20 $\mu$ gram/gram, $25 \mu \mathrm{gram} / \mathrm{gram}$ and $30 \mu \mathrm{gram} / \mathrm{gram})$ have characteristics and values that nearly match those of table 2 . 


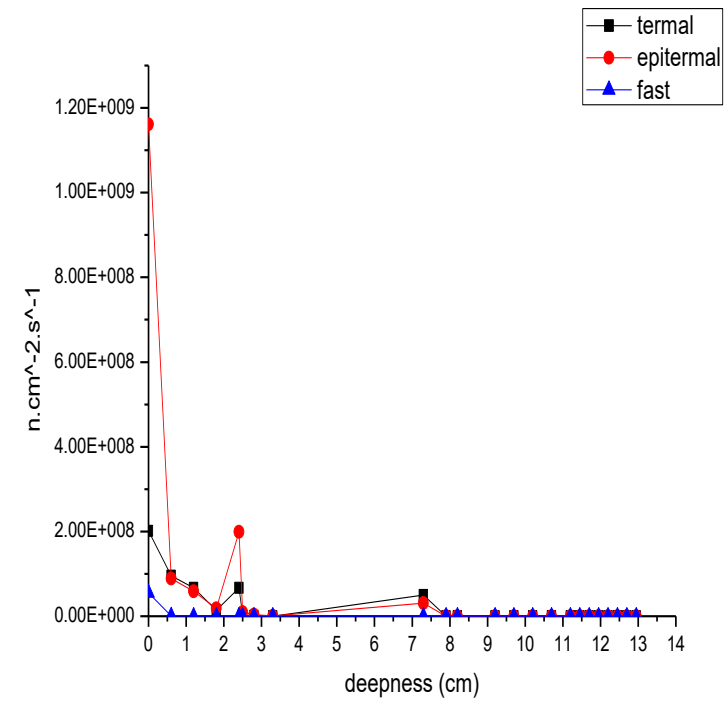

Fig 1. Forms of neutron flux

Figure 1 shows three form of fluxes. These are thermal flux, epithermal flux and fast neutron. When a boron concentration was injected at $35 \mu$ gram/gram cancer, epithermal flux on the skin surface was $1,61 \mathrm{E}+09$ n. $c m^{-2} \cdot s^{-1}$. Thermal flux was $2,011+08$ n. $c m^{-2} \cdot s^{-1}$.

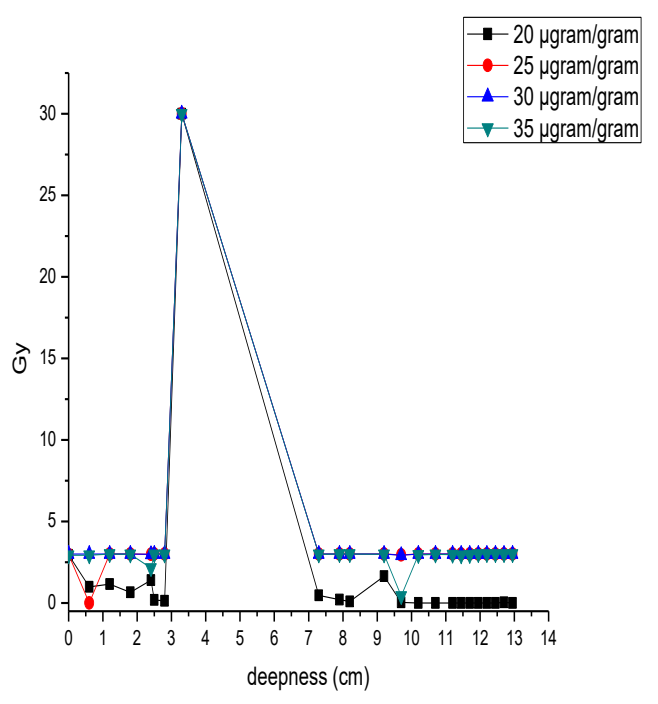

Fig 2. Total Absorption Dose
Total absorption dose is a multiplication of dose rate and time irradiation where time irradiation was obtained from minimal dose destroyer of cancer (on Gy). The minimal dose limit that was used on this simulation was 30 Gy. The time irradiation can be seen on table 3.

Table 3. Dose rate and time irradiation on the cancer tissue.

\begin{tabular}{lccc}
\hline $\begin{array}{c}\text { Boron } \\
\text { concentr } \\
\text { a-tion }\end{array}$ & $\begin{array}{c}\text { Total } \\
\text { Dose } \\
\text { (Gy/ } \\
\text { second) }\end{array}$ & $\begin{array}{c}\text { Time } \\
\text { irradiatio } \\
\text { n for 30 } \\
\text { Gy } \\
\text { (second) }\end{array}$ & $\begin{array}{c}\text { Time } \\
\text { irradiatio } \\
\text { for 30 } \\
\text { Gy } \\
\text { (minute) }\end{array}$ \\
\hline $\begin{array}{l}20 \\
\mu \text { g/gram } \\
\text { cancer }\end{array}$ & $\begin{array}{c}0.00029 \\
25\end{array}$ & 10029,48 & 167,16 \\
$\begin{array}{l}\mu \text { g/gram } \\
\text { cancer }\end{array}$ & 0.0003 & 100000,3 & 166,67 \\
$\begin{array}{l}30 \\
\mu \text { g/gram } \\
\text { cancer }\end{array}$ & 0.00030 & 9956,24 & 165,94 \\
$\begin{array}{l}35 \\
\mu \text { g/gram } \\
\text { cancer }\end{array}$ & 0.00029 & 10071,26 & 167,85 \\
\hline
\end{tabular}

In Table 3, the time needed for irradiation can be seen. The irradiation time needed on the boron concentration at $30 \mu \mathrm{g} / \mathrm{gram}$ cancer was shortest. Table 4 shows the deterministic effect on skin. Deterministic effect can be known based on the optimum dose that can be absorbed by tissues. 
Table 4. Deteriministic effect on skin (Bapeten, 2015).

\begin{tabular}{lcc}
\hline Radiation effect & $\begin{array}{c}\text { Dose } \\
\text { range } \\
\text { (Gy) }\end{array}$ & Time \\
\hline Beginning eritema & $2-3$ & $\begin{array}{c}6-24 \\
\text { hours }\end{array}$ \\
$\begin{array}{l}\text { Epilasi and dry } \\
\text { deskuamasion }\end{array}$ & $3-12$ & $3-6$ weeks \\
$\begin{array}{l}\text { Wet Deskuamasi } \\
\text { Nekrosion }\end{array}$ & $\begin{array}{c}12-20 \\
\text { 420 }\end{array}$ & $\begin{array}{l}\text { 4-6 weeks } \\
10 \text { weeks }\end{array}$ \\
\hline
\end{tabular}

Table 5. The estimated deteriministic effect on the skin

\begin{tabular}{ccc}
\hline $\begin{array}{c}\text { Boron } \\
\text { Concentration }\end{array}$ & $\begin{array}{c}\text { Range dose } \\
\text { absorbed on } \\
\text { skin(Gy) }\end{array}$ & $\begin{array}{c}\text { Estimated } \\
\text { effect that } \\
\text { accepted }\end{array}$ \\
\hline $\begin{array}{c}20 \mu \mathrm{g} / \text { gram } \\
\text { cancer }\end{array}$ & 0.99 & -- \\
$\begin{array}{c}25 \mu \mathrm{g} / \mathrm{gram} \\
\text { cancer }\end{array}$ & 0 & -- \\
$\begin{array}{c}30 \mu \mathrm{g} / \mathrm{gram} \\
\text { cancer }\end{array}$ & -- & -- \\
$\begin{array}{c}35 \mu \mathrm{g} / \text { gram } \\
\text { cancer }\end{array}$ & 2.93 & $\begin{array}{c}\text { Beginning } \\
\text { eritema }\end{array}$ \\
\hline
\end{tabular}

Table 5 shows that in the concentrations of $20 \mu \mathrm{g} / \mathrm{gram}, 25 \mu \mathrm{g} / \mathrm{gram}$ and $30 \mu \mathrm{g} / \mathrm{gram}$ cancer no effect was made on skin. Boron concentration $35 \mu \mathrm{g} / \mathrm{gram}$ cancer gives the deteriministic effect of beginning eritema. Eritema is a redness skin phenomenon because of capillary artery widening that cause the highest radiation exposure(Setiyadi, Sardjono, \& Darmawan, 2016; Young \& Kerr, 2002).

\section{CONCLUSION}

Based on the calculations, with the optimum concentration of Boron-10 in tumour tissue was $30 \mu \mathrm{g} / \mathrm{gram}$ tumour the radiation dose in the skin was less than $3 \mathrm{~Gy}$. The optimum irradiation times was 2.79 hours for concentration $20 \mu \mathrm{g} / \mathrm{gram} ; 2.78$ hours for concentration $25 \mu \mathrm{g} / \mathrm{gram} ; 2.77$ hours for concentration $30 \mu \mathrm{g} / \mathrm{gram}$; $2 ., 8$ hours for concentration $35 \mu \mathrm{g} / \mathrm{gram}$.

\section{ACKNOWLEDGEMENT}

The authors would like to express their thanks to those who took roles for the accomplishment of the project, especially for Susilo Widodo, the Head of Center for Accelerator and Material Process Technology (BATAN), for the opportunity given to do this work.

\section{REFERENCES}

American Cancer Society, I. (2014). Cancer Facts and Figures. Retrieved from https://www.cancer.org/content/dam/can cer-org/research/cancer-facts-andstatistics/annual-cancer-facts-andfigures/2014/cancer-facts-and-figures2014.pdf

Bakirdere, S., Orenay, S., \& Korkmaz, M. (2010). Effect of Boron on Human Health. The Open Mineral Processing Journal, 3(1), 54-59. https://doi.org/10.2174/18748414010030 10054

Cember, H., Johnson, T. E., \& Alaei, P. (2009). Introduction to Health Physics: Fourth Edition. Medical Physics (Vol. 35). https://doi.org/10.1118/1.3021454

Fauziah Nina, Widiharto, A., \& Sardjono, Y. (2015). Jurnal teknologi reaktor nuklir Tri Dasa Mega:Pusat Teknologi dan Keselamatan Reaktor Nuklir (Indonesia), A Conceptual Design of Neutron Collimator in The Thermal Column of Kartini Research Reactor for in Vitro and in Vivo Test of Boron Neutron Capture Therapy (Vol. 15). Retrieved from http://jurnal.batan.go.id/index.php/tridam 
/article/view/1868

IAEA. (2014). PACT :Together Against Cancer.

Sauerwein, W. (1993). Principles and history of neutron capture therapy.

Strahlentherapie Und Onkologie: Organ Der Deutschen Rontgengesellschaft ... [et Al], 169(1), 1-6. Retrieved from http://www.ncbi.nlm.nih.gov/pubmed/84 34333

Sauerwein, W. A. G., \& Moss, R. L. (2009). Requirements for Boron Neutron Capture Therapy (BNCT) at a Nuclear Research Reactor. https://doi.org/10.2790/11743

Setiyadi, A., Sardjono, Y., \& Darmawan, D. (2016). Dosis Boron Neutron Capture Therapy (BNCT) pada Kanker Kulit (Melanoma Maligna) menggunakan MCNPX- Code dengan Sumber Neutron dari Beamport Tembus Reaktor. Jurnal Fisika, 5, 65-75.

Sudhakar, A. (2009). History of Cancer, Ancient and Modern Treatment Methods. Journal of Cancer Science \& Therapy, 1(2), 1-4. https://doi.org/10.4172/19485956.100000e 2

Young, R. W., \& Kerr, G. D. (2002). Reassessment of the atomic bomb radiation dosimetry for Hiroshima and Nagasaki. Retrieved from https://inis.iaea.org/search/search.aspx?o rig_q=RN:39019932 